\begin{tabular}{ccc}
\hline International Journal of Engineering \& Technology, $7(3.2)(2018) 269-274$ \\
SPC & Website: $w$ ww. sciencepubco.com/index.php/IJET \\
Research paper & Technology \\
\hline
\end{tabular}

\title{
Vibrated Soilcement Piles
}

\author{
Tetiana Nesterenko ${ }^{1}$, Oleksandr Novytskyi ${ }^{2}$, Serhiy Voskobiynyk ${ }^{3}$ \\ ${ }^{I}$ Poltava National Technical Yuri Kondratyuk University, Ukraine \\ ${ }^{2}$ prjsc "SUMBUD" Main Testing Laboratory In Construction, Ukraine \\ ${ }^{3}$ Poltava National Technical Yuri Kondratyuk University, Ukraine \\ *Corresponding Author E-Mail: Novitskiy.A.P@Gmail.Com
}

\begin{abstract}
The article describes the vibration research effect of on strength increasing and soilcement density. Laboratory studies of vibration impact on soilcement during manufacturing on the basis of loam and sandy soils have been performed. The field experimental determination of deep high-frequency vibration influence on soilcement piles material characteristics has been fulfilled. The process of material shrinkage during manufacture has been investigated. The obtained results are introduced in the process of soilcement base and foundations placement. Field comparative tests with static compressive loading of three types of piles, including vibro-compacted soilcement piles, have been conducted. With the PLAXIS software system, and with it's axisymmetric particular version, the relationship between loading and soilcement piles settling was established. Numerical stamp tests modeling with the help of the software system PLAXIS was performed to detect the soilcement vibration influence on the reinforced base deformation.
\end{abstract}

Keywords: soilcement, deep soil mixing method, high frequency vibration, soilcement piles, reinforced base, numerical modeling, Plaxis.

\section{Introduction}

Modern buildings grow ever higher up to heaven, thereby the buildings weight increasing themselves, and with it load on the foundation and base, respectively. Taking into account the mankind desire to be in the events center, there is a tendency towards the most efficient each land plot development in the central parts of the cities of Ukraine and the world.

These factors lead to the fact that the large cities centers are densely built by skyscrapers. Taking into account that the load on the base is rather substantial, it is shallow foundation impossible to use the, in addition to the slab bases, which in turn are very valuable.

To place pile foundations is possible solution. The tight conditions of building do not allow the reinforced concrete piles bloking by diesel and hydro-hammers. The rational solution is to use drilling piles.

To reduce pile foundation price, it is necessary to use soil that lies at the buildingbase. In the study of world experience, one can distinguish a method of soils saturation by cement, in result we have material of rather high soilcement strength. Due to the use of deep soil mixing method of soils saturation by cement, it is possible to arrange vertical cylindrical soilcement piles of specified length and diameter.

Thus, soilcement piles use is the most rational and economical method for foundation constructing under the proposed conditions.

\section{Analysis of Recent Research and Publica- tions}

Analysis of domestic and foreign literary sources, where issues of the method of arrangement of soilcement piles, soilcement physical and mechanical properties, methods of its strength increasing, etc. are considered. Well known scientists worked on these issues: Abelev Yu.M., Boyko IP, Bezruk V.M., Easter Yu.Y., Vinnikov Yu.L., Gotman A.L., Gotman N.Z., Dalmatov BI, Zotsenko ML, Kirichek Yu.O., Kornienko MV, Krisan VI, Lartseva II, Marchenko VI, Morgun AS, Petrash R V.V., Tokin OM, Cruz RC, Consoli NC, Puppala J., Bhadriraju V., Porbaha A., Rutherford CJ, Cesare Melegari Yang, TS etc.

It is noted that the most promising method of soilceement elements manufacturing is deep mixing, when the soil in the wells is crushed and saturated slurry with a water-cement with mixing by a special stirrer (a drill tool). It is also established that the soilcement strength is influenced by soil type, cement content, quality of mixing, conditions and term of tufts, the water-cement mixture ratio and some additives presence. Strong soilcement is made of sandy soils, which is tight in water-soaked soils, with cement content $15-25 \%$. In time, which has been traced for 2 years, the soilcement strength has been significantly increased. Essentially increases the soilcement strength of its consolidation by static load during factory design. In this case, the mixture removes air and water entrapped, but achieves a more dense location of components. This positively effects the product quality, as a result, its strength, reduced water resistance, frost resistance, corrosion resistance, shrinkage and durability increases significantly. In the deep soil mixing method, such sealing of the cement mixture is not possible. According to our data, the vibrational method of the cement mixture sealing was not investigated.

\section{Formulating the Goals of the Article}

The soilcement piles disadvantage is the relatively less material durability due to the absence of large aggregates in the soilcement. This leads to the fact that sometimes the bearing capacity of piles 
on the ground may be greater than the bearing capacity of piles on the material, which leads to an increase in the number of piles.

Deep vibration compaction of piling material is proposed to solve the revealed problem.

\section{The Main Research Material}

On the basis of the laboratory of the department of technology building designs, products and materials of Poltava National Technical Yuri Kondratyuk, laboratory studies were carried out on vibrations of soilcement. In laboratory studies of soilcement vibration there was used shallow loam and quartz small, uniform sand. There was used portland cement of PC-II / B-W-400 and hydro-carbonate-calcium, slightly alkaline water with $\mathrm{pH}=8$ the content of portland cement was $20 \%$ from the weight of dry soil. Shallow loam soilcement was prepared by parties of mix cement ratio $\mathrm{W} / \mathrm{C}=1,5 ; 1,75$ and 2,1 . Sandy soilcement had $\mathrm{W} / \mathrm{C}=1,75$ and 2,1. Samples of soilcement were formed in special metal cubic forms with dimensions grane of $100 \mathrm{~mm}$, then the forms with soilcement were weighed. To create a reserve of liquid soilcement added to form a nozzle height of $50 \mathrm{~mm}$. Vibrate samples in the form of a nozzle were performed on standard laboratory vibration stand at a frequency of oscillation $\mathrm{n}=50 \mathrm{~Hz}$ and amplitude fluctuations under load $\mathrm{A}=0,5 \mathrm{~mm}$. After vibrating the nozzle was removed, and the remains of soilcement were cut in such form (Figure 1). a)

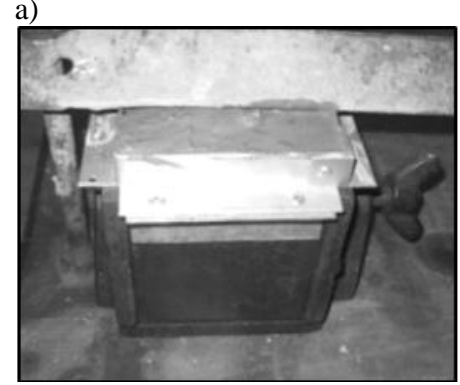

c)

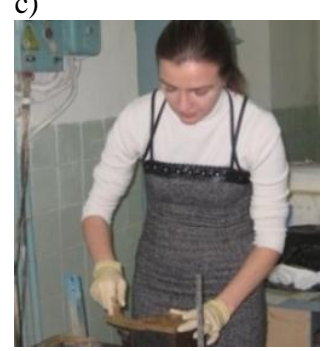

b)

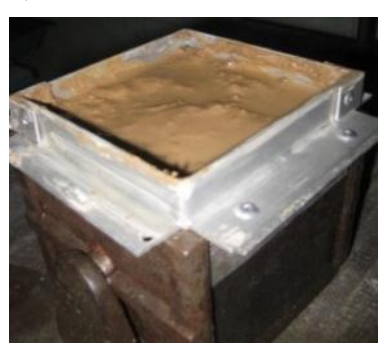

d)

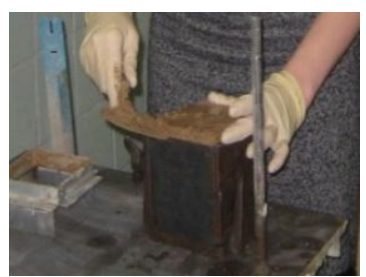

Fig. 1 Formation of soilcement samples in the form with additional attachment: a) - the beginning of creation, b) - the completion , c, d) - cuting of soilc ment remains

There was for axial compression samples test used universal testing machine by designs HMS-50. The results of determining strength of vibrated soilcement depending on time of vibration are shown in Figure 2. From the graph it is obvious that the sandy soilcement (curves 3 and 4), has great or strength ratios than soilcement with shallow loam soil (curves 1 and 2). Initial indicators of cubes strength for samples from shallow soilcement homogeneous sand (without vibration) with the application of vibration influence were increased by $40 \%$ and $44 \%$, respectively, for W/C 1,75 and 2.1. For shallow loam soilcement strength at the same values of W/C increased by $78 \%$ and $66 \%$. Maximum cubic strength is achieved by application of vibration for $120 \mathrm{sec}$ for samples with homogeneous shallow sand and $300 \mathrm{sec}$ for samples with shallow loam soil. The density of the sand soilcement increased by $6 \%$, and from loam - $8 \%$.

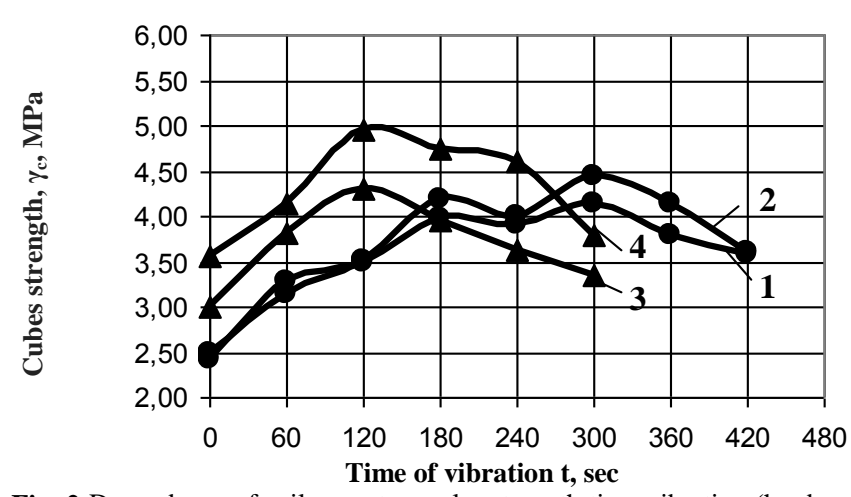

Fig. 2 Dependence of soilcement samples strength time vibration (hardening time 28 days): 1 - of shallow loam soil with $\mathrm{W} / \mathrm{C}=2,1 ; 2$ - a loam soil with $\mathrm{W} / \mathrm{C}=1,75 ; 3$ - a shallow sand $\mathrm{W} / \mathrm{C}=2,1 ; 4$ - a homogeneous sand with $\mathrm{W} / \mathrm{C}=1,75$

Thus, there has been experimentally proven soilcement effect of increasing strength, which is made of shallow loam soils, due to vibration of soilcement mixture. The same is due to quartz shallow, homogeneous sands. Also, it is proved that there exists an optimal value of vibration intensity (duration of vibration) when for a particular composition of soilcement mixture there is achieved maximum soilcement density. At greater intensity of vibration soilcement stratified mixture. The reason for increased strength of soilcement is the increase of it's density due to vibration. A sealing effect of soilcement mixture by vibrations occure due to displacement of from it water and air bubbles. At higher values of watercement ratio the relative increase of soilcement strength is of tendence. But with the increase of the given soil moisture - soilcement samples strength decreases. Thus, samples that had the lowest soil moisture (18\%) have the highest strength.

There was improved the method of calculation of time compaction by vibrations of soilcement samples for specific initial conditions and parameters of the applied vibration. Thus, according to the calculation data of the maximum liquid seal soilcement was 167.5 $\mathrm{s}$, which gives sufficient convergence with the results of laboratory determinations in $180 \mathrm{~s}$.

Since the soilcement, in the process of drill-mixing, is a mildly dispersed medium, an increase in the oscillation frequency compared to the standard frequency for concrete is $50 \mathrm{~Hz}$ is necessares for its more effective sealing. The oscillation frequency of the deep-shaped vibratory vibrators reaches $280 \mathrm{~Hz}$. Thanks to flexible shafts, vibration depths up to 12 meters can be increased, which allows you to vibrate throughout the length of the pile. Depth vibrators consist of a vibrating feeder, a flexible shaft, and alternating of different diameter diameters.

In cooperation with LLC "Fundament-investbud", in-depth studies of sealing material of soilcement piles in diameter of $500 \mathrm{~mm}$ deep vibrators during construction of a residential building of the Esplanade district building 29 in Sumy were conducted.

The piles were arranged by the deep soil mixing method without removing the soil by hinged drilling equipment installed on the РДК-250; the water-cement solution was fed through a swivel connected with the feeder CO-2 (Fig. 3). Mixing and injection of a water cement solution was used a $1 \mathrm{~m}^{3}$ mixer and a CO-50 pump (Fig. 3).

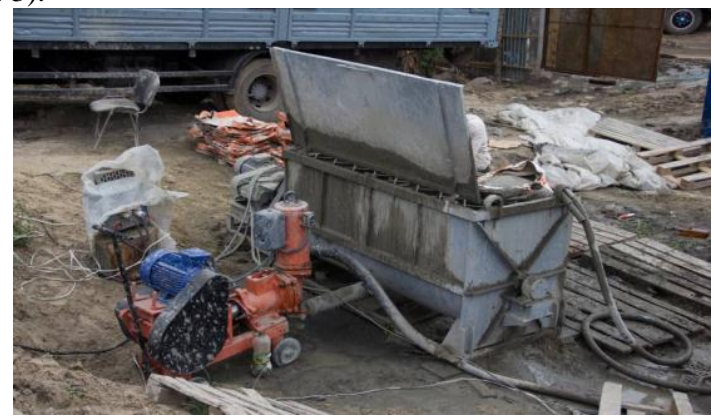

Fig.3 The complete set of the equipment for supply of water-cement mortar, pump CO-50 and blade mixer. 
For vibration sealing, a deep vibrator IV-117 was used with a pin D76, depicted in Fig. 5

To determine the degree of impact of deep vibration on durability, three cemented cab lengths of $2 \mathrm{~m}$ were made. High-frequency deep vibration was performed for two piles.

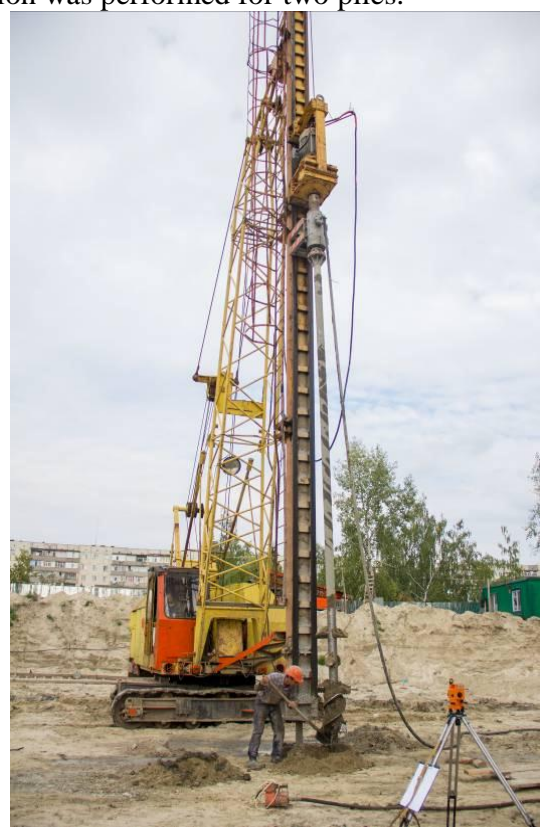

Fig.4 Equipment for placement of soilcement foundations with highfrequency deep vibrating: a - RDK-250 with hinged drilling equipment;

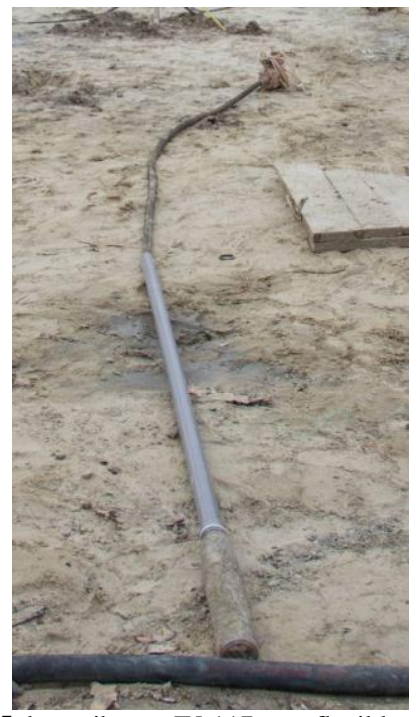

Fig.5 deep vibrator IV-117 on a flexible shaft.

a)

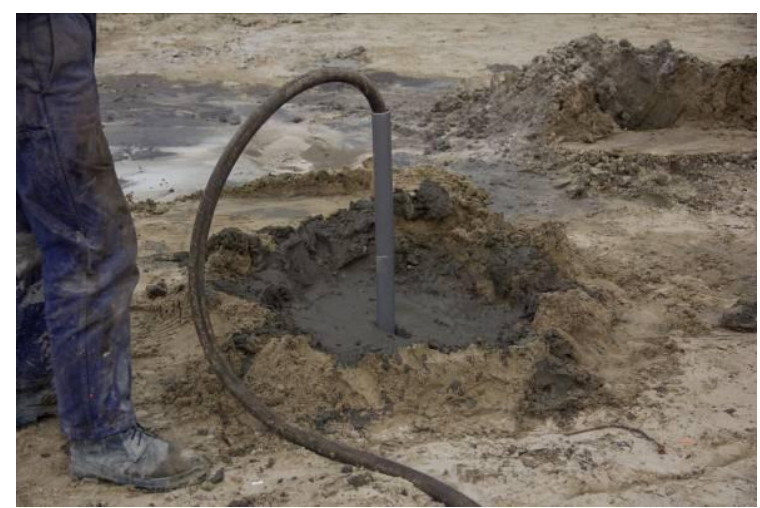

b)

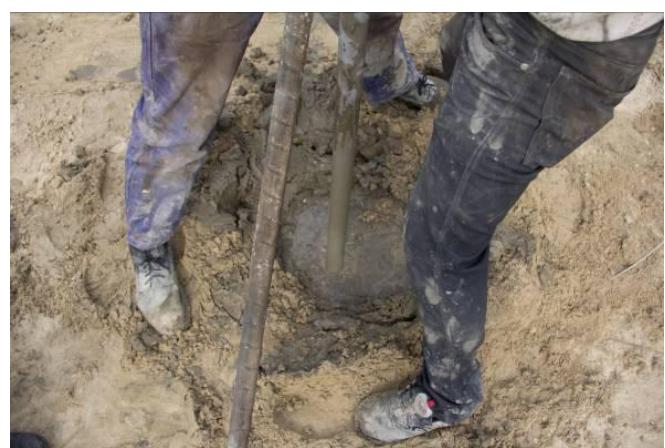

Fig. 6 The process of deep vibration: a - initial immersion to five piles; b displacement of the vibrator.

The process of moving the tip of the vibrator from the five piles to its headband allows to extract the air from the pores that were formed during the piles' placement and remove the excess water in the soil surrounding the spit as effectively as possible.

The three experimental piles were made directly on the construction site, the soil of the base - alluvial sand of medium size, not lost.

Vibration for Pile №1 was not performed, Piles № 2 and № 3 were checked. The vibration time of the piles was monitored gradually, the transition to the next conquest was carried out after the termination of the sediments of the material during the previous invasion.

Immediately after the piles piling, the material's obsolescence was monitored.

Pile №1 settled on $102 \mathrm{~mm}$. A day later, the extra settling pile was $26 \mathrm{~mm}$.

For pile number 2 , the time for vibration was 7 minutes $30 \mathrm{se}$ conds, for this the period of subsidence of the material of the pile from the seal was $189 \mathrm{~mm}$. Additional deposition after vibration sealing was monitored during the cement fixation period and after 2 hours was $1 \mathrm{~mm}$. After a day of subsidence did not increase.

For pile number 3 , the time for vibration was 8 minutes, during which the period of subsidence of the pile material from the seal was $130 \mathrm{~mm}$. Additional settling in 2 hours was $12 \mathrm{~mm}$. After a day of subsidence did not increase.

For Pile № 1, a considerable subsidence of the material was observed in the course of the day, with the formation of shallow cracks on the surface of the headband (Fig. 5b), with the formation of a conical depression. For piles with vibration pressure, the formation of deepening and cracking was not detected.

a)

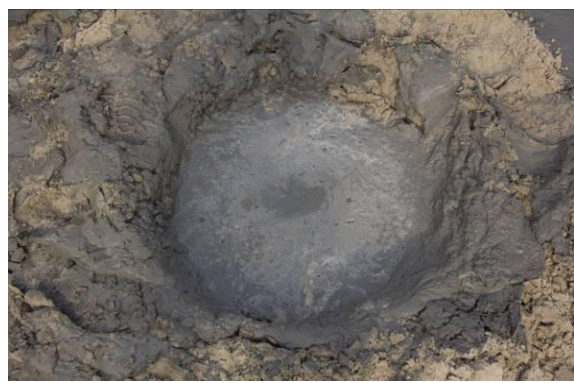

b)

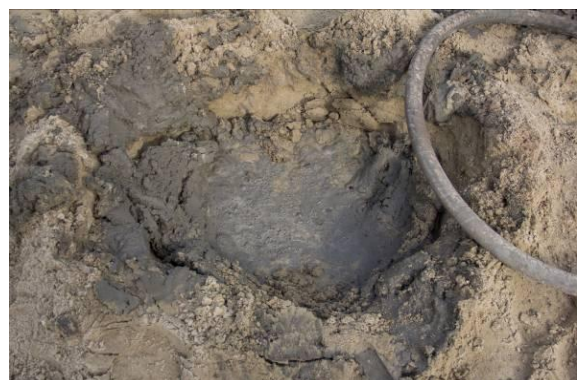

Fig.7 Condition of the piles of experimental piles one day after placement: $\mathrm{a}$ - the pile is made with vibration; $\mathrm{b}$ - the pill is made without vibration. 
The strength of the piling material was checked after 28 days after installation. Palaces were excavated and examined (Fig. 7a). On the shaft of the pile that vibrated were not notes of the stratification of the material. The diameter and length of the pile №1 corresponded to the design, the diameter of the piles number 2 and number 3 was 520 to $530 \mathrm{~mm}$. The completed cross section of the piles visually showed a greater porosity of the pile №1.

The durability of the ball material was determined by two methods:

- non-destructive, by ultrasonic method;

- destructive, determination of the strength of samples of soilcement with the help of a hydraulic press.

a)

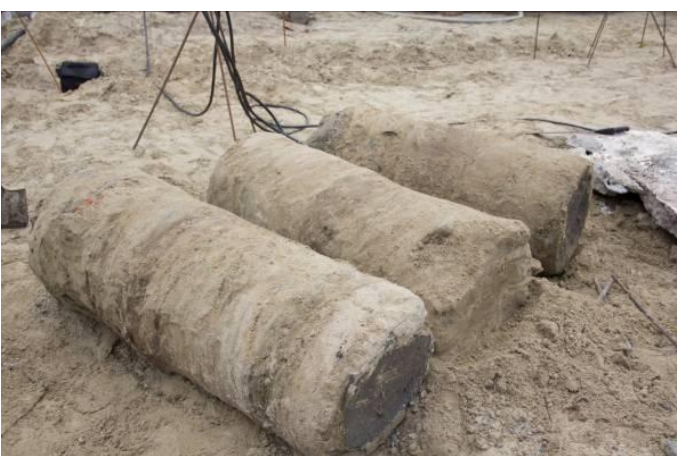

b)

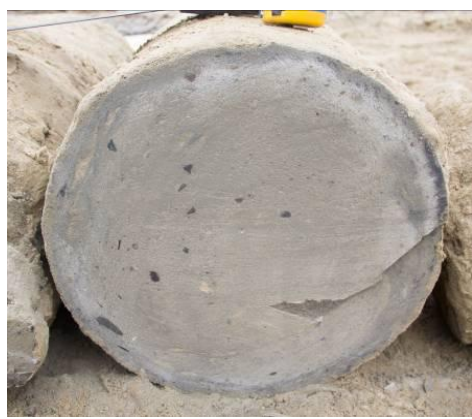

Fig. 8 Digested experimental cement piles after 28 days after placement: a - the excavated piles; $\mathrm{b}$ - a cut of the excavated pal, which was checked.

a)

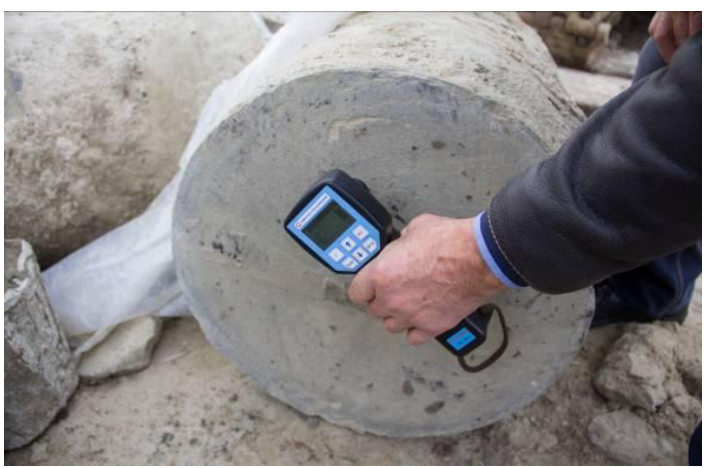

b)

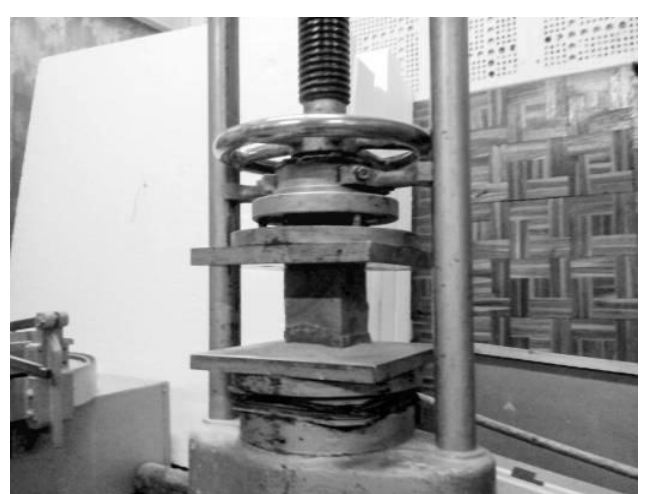

Fig. 9 Determination of pile material strength: a - determining the strength of the material by means of a non-destructive ultrasonic method on the slice of the pile; $b$ - Determination of the strength of selected samples of soilcement with the help of a press.

The values of the results of cubic strength and density of soilcement are given in Table 1.

Table 1: Averaged results of determining the characteristics of a material of soilcement piles by non-destructive method

\begin{tabular}{|c|c|c|c|c|c|}
\hline \multirow{2}{*}{$\begin{array}{c}\text { № } \\
\text { pile }\end{array}$} & \multicolumn{2}{|c|}{$\begin{array}{c}\text { Non-destructive ultra- } \\
\text { sonic method }\end{array}$} & \multicolumn{3}{|c|}{ Destructive method } \\
\cline { 2 - 6 } & $\begin{array}{c}\text { Strength, } \\
\mathrm{MPa}\end{array}$ & $\begin{array}{c}\text { Coeffi- } \\
\text { cient of } \\
\text { variation, } \\
\mathrm{V}\end{array}$ & $\begin{array}{c}\text { Density } \\
\rho, \\
\mathrm{t} / \mathrm{m}^{3}\end{array}$ & $\begin{array}{c}\text { Strength, } \\
\mathrm{MPa}\end{array}$ & $\begin{array}{c}\text { Coeffi- } \\
\text { cient of } \\
\text { variation, } \\
\mathrm{v}\end{array}$ \\
\hline 1 & 2,99 & 0,26 & 2,162 & 3,08 & 0,312 \\
\hline 2 & 5,1 & 0,069 & 2,283 & 5,46 & 0,126 \\
\hline 3 & 4,88 & 0,047 & 2,213 & 5,17 & 0,096 \\
\hline
\end{tabular}

The obtained results show the positive effect of vibration compaction on the strength and soilcement density. The strength of the material of the piles, which was monitored by $63-77 \%$, and the density increased by $2,4-5,6 \%$. Paying attention to the coefficient of variation can be noted more stable durability of the material of compacted piles.

A series of field trials was continued by the manufacture of field piles and their subsequent testing on the construction site with the help of equipment LLC "Fundamentbud-3".

For comparison, three types of tested non-reinforced piles were made within the construction site, with a hardening time of 56 days.

- I series of two drill piles of concrete C16/20 with a diameter of $500 \mathrm{~mm}$ and a length of $6 \mathrm{~m}$, with guaranteed load carrying capacity on a material more than a ground;

- II series of two cementitious piles with a diameter of $500 \mathrm{~mm}$ and a length of $6 \mathrm{~m}$, performed by a blended method without vibration;

- III series of three cement piles with a diameter of $500 \mathrm{~mm}$ and a length of $6 \mathrm{~m}$, which were performed according to the deep soil mixing method with the vibration of the liquid mixture.

For the computing experiment, the software complex PLAXIS 8.2 was chosen, namely its axisymmetric version, using the traditional model of the Moore-Coulon soil in the form of elastic-plastic loading and stacking of piles according to the axisymmetric version of the PLAXIS software complex on the basis of the following provisions:

- it is believed that the material of the concrete pile has an infinite rigidity; according to these data, the bearing capacity at the vertical loading on the ground of the packing pile of the accepted sizes is established;

- for a packing pile, which is made of soilcement in a blasting environment technology, which requires the following output data: the angle of dilatation, the angle of internal friction, the deformation module, the specific clutch, without vibration, the rigidity is accepted according to experimental research data; At the same time, we believe that the amount of its subsidence under the vertical load in the plastic stage predominantly depends on the deformation of the soilcement;

- We accept the same thesis for a vibrating soilcement pile, which is made by blasting method with vibration and received the corresponding rigidity.

According to the results of the simulation, the graphs of the dependence of piles settling under load were constructed (Fig. 10). According to the graphs of fig. 10, at the deformation of $2 \mathrm{~cm}$, the values of the bearing capacity of the experimental piles are determined. From the analysis of the graphs it can be seen that the "breakdown" of the soilcement pile (i.e., its loss of bearing capacity) occurred when the load reached $320 \mathrm{kN}$, and then there was a significant increase in plastic deformations. This is confirmed by ispoly of general deformations, which show that the most deformed body itself is the palm in its upper part, indicating the destruction of the material. 
Comparison of graphs in Fig. 9, indicate a sufficient coincidence of experimental data and calculation. This testifies to the reliability of the research carried out on the effect of vibration of soilcement elements in the process of their manufacture by the deep soil mixing method.

\section{Pile loading $\mathbf{P}, \mathbf{k N}$}

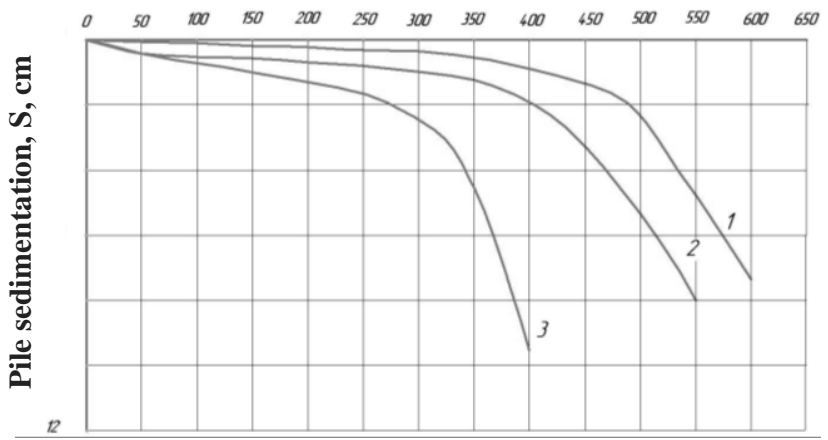

Fig. 10. Dependence of sedimentation on the load on results of modeling in axisymmetrical formulation: 1 - drilling stuffed concrete pile; 2 - soilcement vibrated pile; 3 - soilcement pile

Numerical modeling of stamp tests was carried out to detect the influence of vibrations of soilcement on the deformation of reinforced base.

Used soilcement reinforced elements in diameter of $0,5 \mathrm{~m}$ and in length of $5,7 \mathrm{~m}$. Floor reinforced array arranged intermediate layer in thickness of $0,3 \mathrm{~m}$ to exclude contact between reinforcing elements and stamps. Floor this layer square stamp in the form of plate element with a side $1,2 \mathrm{~m}$, assigned the physical and mechanical properties of concrete. On the stamp was applied evenly distributed over it's area load directed vertically downward. Calculations was performed by stepper-iterative procedure. From these data built graphs sedimentation stamp on the load for three cases:

- Stamp set on a natural basis;

- Stamp set on basis reinforced by soilcement elements;

- Stamp set on basis that reinforced by vibrated soilcement elements.

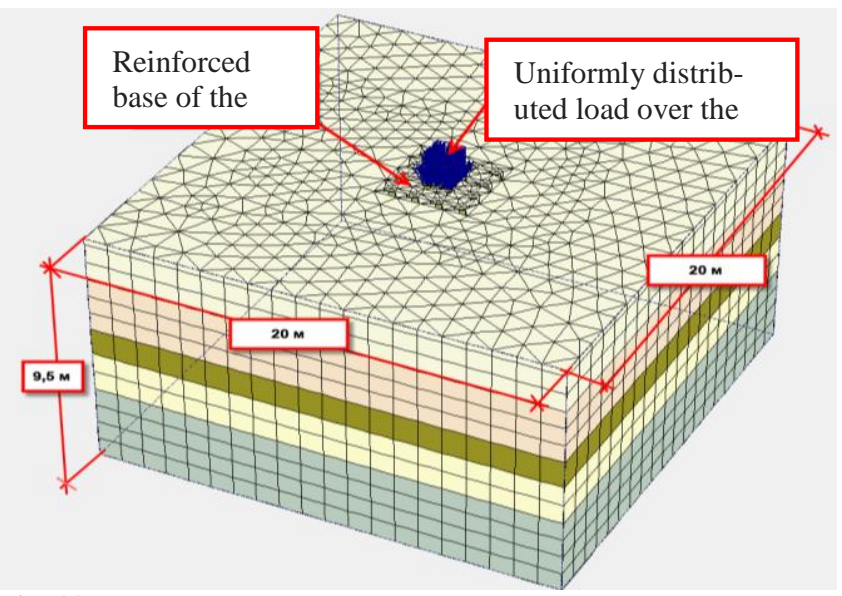

Fig. 11 General view of the geometric model to model stamping trials of the reinforced base

Relevant graphics "sedimentation - load" are shown in Figure 8 According to the formula Schleicher obtained values of deformation modulus for the three cases of the calculation: natural basis $\mathrm{E}=8,0 \mathrm{MPa}$; basis, reinforced by soilcement elements $\mathrm{E}=18$ $\mathrm{MPa}$; base reinforced by vibrated soilcement elements $\mathrm{E}=18$ MPa.

The dependences show that reinforcement increases the bearing capacity of the base: plastic (nonlinear) stage of deformation reinforced base stamp comes at a pressure of about $200 \mathrm{kPa}$, while not vibrated reinforced elements about $600 \mathrm{kPa}$, and vibrated - about $800 \mathrm{kPa}$.
Regarding the deformation behavior of reinforced base, the simulation results have shown this parameter in the linear stage does not depend on the soilcement characteristics, it meens that vibration does not effect on the nature of the deformation.

Loading on stamp, $\mathbf{P}, \mathrm{kN}$

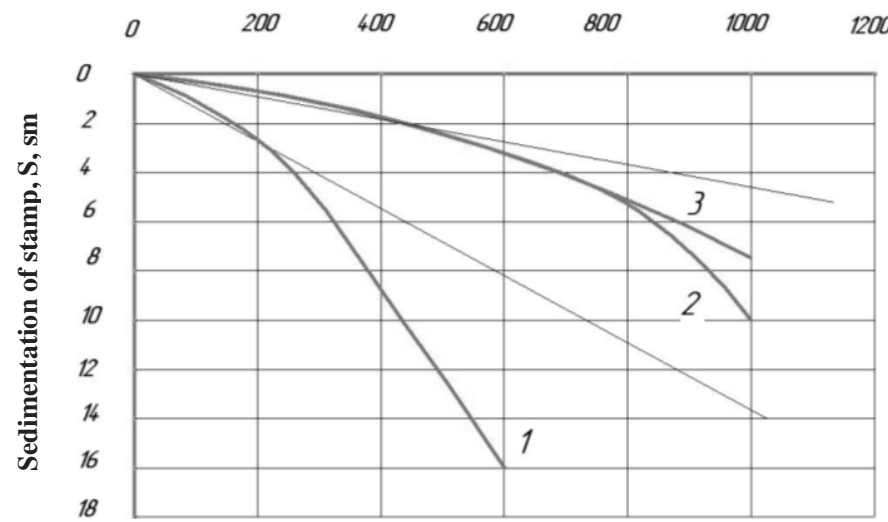

Fig. 12 graphics of depending subsidence of stamp basics of the load by modeling results: 1 - for stamp on the natural basis; 2 - for stamp on the reinforced by soilcement elements basis made without vibration; 3 for stamp on the reinforcing soilcement elements basis, manufactured with using vibration

\section{Conclusion}

1. According to laboratory data, the effect of increasing the density of soilcement, which is made of dusty shallow loam soils or of shallow homogeneous sand due to vibration of the soilcement mixture, has been proved. In this case, the optimal value of the intensity of vibration, when for a certain composition of the soil cement mixture, reaches the maximum value of the density of the material, and the strength of the vibrating soilcement after 28 days of tensing increases to $30 \%$.

2. Experimental field investigations carried out on the influence of deep-high vibration compaction of soilcement piles showed a positive result. When using vibration, the porosity of the material decreases, there is no stratification, and no cone-shaped recesses and cracks are formed on the surface of the pile header. Deep high-frequency vibration sealing increases the strength of soilcement pile that was compacted by $63-77 \%$, with a density increase of 2.4-5.6\%. The use of deep vibration sealing when placing soilcement piles is a mandatory step in the deep soil mixing method and requires more detailed research.

3. To evaluate the stress-strain state of the system "base - soilcement piles" an elastic-plastic model of soil is adopted. With the PLAXIS software system, and in particular its axisymmetric version, the relationship between loading and settling of soilcement piles was established. It is proved that in the investigated engineering-geological conditions of vibration of soilcement increases the bearing capacity of the piles on the material by $30-60 \%$. Regarding the reinforced bases, using the version of "PLAXIS 3D Foundation" within the framework of the spatial task, it has been shown that increasing the strength of the soilcement due to vibration does not affect the compressibility of the reinforced base. These conclusions of the calculation experiment are close to the data obtained in the field.

\section{Acknowledgement}

Special thanks from the authors for the scientific tutor the professor, D.Sc Zotsenko M. And also, thanks for the cooperation and assistance in conducting field experiments to the management and co-workers of LLC Fundamentbud-3 and LLC Fundamentinvestbud. 


\section{References}

[1] Drilling soilcement piles which are produced by drillingmixing method. Monograph./ M.L. Zotsenko, Yu.L. Vinnikov, V.M. Zotsenko - Kharkiv: "Madrid typography", 2016 - p.94 Il.:59, tab.: 36, bibliographer. 59 titles, appendix 1 .

[2] Zotsenko M.L. Comparative characteristic of buildings and structures foundations from piles and on the reinforced basis. / M.L. Zotsenko, I.M. Sukhorosov, L.M. Zotsenko // Interdepartmental sciences.-techn. collection sciences works (building) / State research sciences of other construction constructions of the Construction Ministry of Ukraine. - K.: NIIBK, 2007. - edition. 66. - pp. 405-409.

[3] Zotsenko N.L. Reducing energy costs at foundation installing / N.L. Zotsenko, M.O. Korshunov, N.F. Peredey // "Industrial construction and engineering constructions". -K: - 1987 - №1. - p. 14-17.

[4] Chrisan V.I. Investigation of the stress-strain state of a soil massif, reinforced by cementitious elements, which made by the jet-mixing technique: author's abstract. dissertation Candidate of technical Sciences: 05.23.02/ V.I. Chrisan; Poltava National Technical Yuri Kondratyuk University - Poltava, 2010. - p. 23 - Ukraine.

[5] Korobko B. (2016), Investigation of energy consumption in the course of plastering machine's work, Eastern-European Journal of Enterprise Technologies, 4/8 (82), 4 - 11. DOI:10.15587/17294061.2016 .73336

[6] Nesterenko T.M. Soilcement base and foundations, which are made with use of vibration: author's abstract. Degree Candidate tech Sciences: special 05.23.02 "Fundamentals and foundations" / T.M. Nesterenko. - Poltava, 2013. - p. 21

[7] Petrash O.V. Soilcement piles which made by the drillingmixing technology: Author's abstract di Cand. tech Sciences: 05.23.02 / Poltava National Technical University named after Yuriy Kondaratiuk. - Poltava: PNTU, 2013. - p. 23.

[8] Novitsky O. .Vibro-reinforced soilcement pile which made according to the drillingmixing method: Atoreferat on candidat dissertation technical Sciences: 05.23.02 / Poltava National Technical Yuri Kondratyuk University. - Poltava: PNTU, 2015. - p. 23

[9] Donald A. Bruce, Ph.D., C.Eng. An Introduction to the Deep Soil Mixing Methods as Used in Geotechnical Applications - U.S. Department of Commerce National Technical Information Service Springfield, Virginia 2000. - 143 c. - FHWA-RD-99-138.

[10] Lambert, S., Rocher-Lacoste, F. and Le Kouby, A. 2012. Soilcement columns, an alternative soil improvement method. International symposium of ISSMGE-TC211. Recent research, advances \& execution aspects of ground improvement works. 31 May-1 June 2012, Brussels, Belgium.

[11] Nicolas Denies, Gust Van Lysebetten, General Report. SESSION 4 - SOIL MIXING 2 - DEEP MIXING. International symposium of ISSMGE - TC 211 International Symposium on Ground Improvement IS-GI Brussels 31 May \& 1 June 2012 